\title{
Seasonal Variability and Environmental Condition of Softwood Grafting in Jamun (Syzygium cumini Skeel)
}

\author{
R. Praveenakumar ${ }^{1 *}$, M. Chandre Gowda ${ }^{1}$ and S. Mounashree ${ }^{2}$ \\ ${ }^{1}$ Department of Horticulture, College of Agriculture, UAS, GKVK, Bengaluru-560065, \\ Karnataka, India \\ ${ }^{2}$ Department of Fruit sciences, College of Horticulture, Mudigere, UAHS, Shivamoga-577132, \\ Karnataka, India \\ *Corresponding author
}

A B S T R A C T

\section{Ke y w ords \\ Softwood grafting, \\ Temperature, Relative \\ Humidity, SPAD, \\ Relative Water Content \\ Article Info \\ Accepted: \\ 22 April 2018 \\ Available Online: \\ 10 May 2018}

Studies on seasonal variability and environmental condition of softwood grafting in Jamun (Syzygium cumini Skeel) was conducted at the Department of Horticulture. GKVK. University of Agricultural Sciences, Bangalore during the period of April 2016 to August 2016. The results of the experiment showed optimum temperature for grafting success in T10 (M4C1: July + low cost polyhouse) $\left(29.69^{\circ} \mathrm{C}\right)$, highest relative Humidity as observed T10 (M4C1: July + low cost polyhouse) (98.83\%), highest SPAD (Chlorophyll content) T7 (M3C1: June + low cost polyhouse) $\left(46.33 \mu\right.$ mol per $\left.\mathrm{m}^{2}\right)$ and highest relative water content observed T9 $\left(\mathrm{M}_{3} \mathrm{C}_{3}\right.$ :June + Open field) (91.10 gm.) highest results are obtained under treatment of $\mathrm{T} 7$ (M3C1: June + low cost polyhouse) and T10 (M3C1: June + low cost polyhouse).

\section{Introduction}

Jamun (Syzygium cumini Skeel) is an important under-utilized and indigenous fruit crop of India belonging to the family Myrtaceae, grown in larger parts of India from Indo-gangetic plains in the North to Tamil Nadu in the South (Singh and Srivastava, 2000). Propagation of Jamun through softwood grafting is gaining popularity among nursery men and growers. Traditionally, Jamun plantations are propagated through seeds in India (Sharma et al., 2004). However, plants raised from seeds are not true to type and eventually take longer time to reach bearing stage. Also propagated through budding but it is cumbersome, and has limitation for large scale and rapid multiplication. Currently softwood grafting is very popular in many fruit crops like jamun (Mulla et al., 1991), sapota (Pampanna and Sulikeri, 2000) and custard apple (Ghosh et al., 2004) in order to overcome budding and seed propagation constraints. Softwood grafting method is easy, convenient in handling, involves simple skill, takes short period, and higher rate of multiplication of plants and resultant plants will be vigorous. Environmental factors play a key role in success of grafting. Low cost polyhouse 
provide cheap simple and very effective in closed environmental conditions for the propagation of plants. The new technology of low cost polyhouse promotes stimulation of many desirable physiological responses which are light regulated. Growing stock plants in full sunlight increased growth attributes. Some of review of literatures shown that low cost polyhouse environment can increase growth of grafts/ plants. However, there are no reports exist concerning softwood grafting of Jamun in different condition. Hence, attempt was made on seasonal variability and environmental conditions of softwood grafting in Jamun.

\section{Materials and Methods}

Studies on seasonal variability and environmental conditions of softwood grafting in Jamun (Syzygium cumini Skeel) as influenced by different growing conditions and different season was carried out during the period from April 2016 to August 2016, at the Department of Horticulture, Gandhi Krushi Vigyana Kendra, Bangalore, University of Agricultural Sciences, Bangalore, Karnataka state. The experiment was conducted to find out the influence of conditions on success of softwood grafting in Jamun. The experiment was laid out in split plot Design with 5 main treatments, sub treatment 3 and 3 replications. Softwood grafting was performed in the month of April. Nine hundred grafts were prepared at the rate of sixty grafts in each treatment and placed under different growing condition viz., low cost polyhouse, shade net and open condition. Root stocks were raised in poly bags from fresh seeds of Jamun extracted from ripe fruits for approximately 8 to 12 months till they attained a stem diameter of 0.5 to $1.0 \mathrm{~cm}$. The scion shoots $(15$ to $18 \mathrm{~cm}$ long) of pencil size thickness with 3 to 4 healthy buds were used for grafting. Selected scion shoots were pre-cured seven days prior to detachment. Softwood grafting was performed in the month of April as per procedure suggested by Amin (1974). The prepared grafts were covered from top by polytube cap. The observation were recorded on graft-take i.e. temperature, Relative Humidity, SPAD (Chlorophyll content), Relative Water Content were recorded at 30 and 120 days after grafting. The data was statistical analysed by following procedure as suggested by Panse and Sukhatme (1967).

\section{Results and Discussion}

The major environmental factors are temperature and relative humidity improves the chlorophyll content, relative water content and post growth behavior of grafting. Low cost polyhouse protect the grafts/ plants from optimum temperature as a resulted reduce moisture stress and decrease the water requirement of plant. In generally a temperature range of $15-30^{\circ} \mathrm{C}$ considered ideal for good cambial contact and for rapid growth of the cambial cells under low cost polyhouse condition, there is rigid control over temperature and relative humidity (Sharma and Srivastav, 2004).

The data in respect of optimum temperature $\left(28.61^{\circ} \mathrm{C}, 33.53^{\circ} \mathrm{C}\right)$ under the month of June $\left(\mathrm{M}_{3}\right)$, low cost polyhouse $\left(\mathrm{C}_{1}\right)$ respectively (Table 1). The above findings revels that certain environmental requirements are must to be met for callus tissue development particularly temperature and relative humidity which influence moister and plant water relation (Bharad and Mahorkar, 2009).

The highest relative humidity $(95.00 \%, 95.15$ $\%$ ) under the month of June $\left(\mathrm{M}_{3}\right)$, low cost polyhouse $\left(\mathrm{C}_{1}\right)$ respectively (Table 1$)$. This could be due to favorable climatic condition like high relative humidity and increase in translocation of food material. Similar results were reported by Mohammad and Mohammad (2005). 
Table.1 Effect of Temperature and relative humidity difference during different months and growing conditions of softwood grafting of Jamun

\begin{tabular}{|c|}
\hline Treatments \\
\hline $\mathbf{M}_{1}$-April \\
\hline $\mathbf{M}_{2}$-May \\
\hline $\mathbf{M}_{3}$-June \\
\hline $\mathbf{M}_{4}$-July \\
\hline $\mathbf{M}_{5}$-August \\
\hline S.Em \pm \\
\hline C.D at 5\% \\
\hline
\end{tabular}

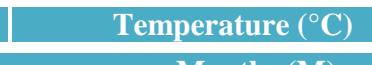

\begin{tabular}{|l|}
\hline \\
\hline
\end{tabular}

$\mathrm{C}_{1}$-Low cost polyhouse

$\mathrm{C}_{2}$-Shade net

$\mathrm{C}_{3}$-Open field S.Em \pm

C.D at $5 \%$

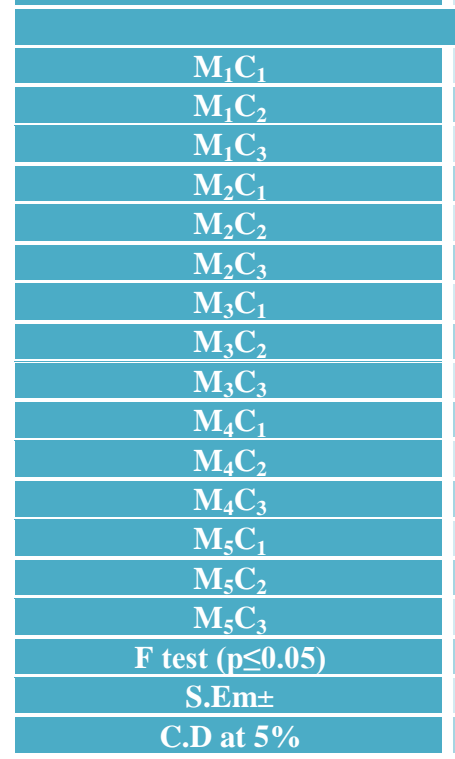

significant

\begin{tabular}{l}
$\mathrm{T}_{1^{-}} \mathrm{M}_{1} \mathrm{C}_{1}$ :April + Low cost polyhouse \\
$\mathrm{T}_{2^{-}} \mathrm{M}_{1} \mathrm{C}_{2}$ :April + Shade net \\
\hline $\mathrm{T}_{3^{-}}-\mathrm{M}_{1} \mathrm{C}_{3}$ :April + Open field \\
$\mathrm{T}_{4^{-}} \mathrm{M}_{2} \mathrm{C}_{1}$ :May + Low cost polyhouse \\
$\mathrm{T}_{5^{-}} \mathrm{M}_{2} \mathrm{C}_{2}$ :May + Shade net \\
$\mathrm{T}_{6^{-}} \mathrm{M}_{2} \mathrm{C}_{3}$ :May + Open field \\
$\mathrm{T}_{7^{-}} \mathrm{M}_{3} \mathrm{C}_{1}$ :June + Low cost polyhouse \\
$\mathrm{T}_{8^{-}} \mathrm{M}_{3} \mathrm{C}_{2}$ :June + Shade net \\
$\mathrm{T}_{9^{-}}-\mathrm{M}_{3} \mathrm{C}_{3}$ :June + Open field \\
$\mathrm{T}_{10^{-}} \mathrm{M}_{4} \mathrm{C}_{1}$ :July + Low cost polyhouse \\
$\mathrm{T}_{11^{-}} \mathrm{M}_{4} \mathrm{C}_{2}$ :July + Shade net \\
$\mathrm{T}_{12^{-}} \mathrm{M}_{4} \mathrm{C}_{3}$ :July + Open field \\
\hline $\mathrm{T}_{13^{-}} \mathrm{M}_{5} \mathrm{C}_{1}$ :August + Low cost polyhouse \\
$\mathrm{T}_{14^{-}} \mathrm{M}_{5} \mathrm{C}_{2}$ :August + Shade net \\
$\mathrm{T}_{15^{-}} \mathrm{M}_{5} \mathrm{C}_{3}$ :August + Open field
\end{tabular}

\begin{tabular}{l|r}
33.14 & 84.63 \\
\hline 33.75 & 88.75
\end{tabular}

\begin{tabular}{l|r}
33.75 & 88.75 \\
\hline
\end{tabular}

\begin{tabular}{r|r}
28.61 & 95.00
\end{tabular}

\begin{tabular}{l|r}
27.08 & 93.83
\end{tabular}

\begin{tabular}{r|r}
30.41 & 92.83
\end{tabular}

\begin{tabular}{r|r|}
0.58 & 0.65 \\
\hline
\end{tabular}

\begin{tabular}{r|r|}
\hline 1.88 & 2.11
\end{tabular}

\begin{tabular}{|c|c|}
\hline Condition(C) & 95.15 \\
\hline 33.53 & 87.37 \\
\hline 28.72 & 90.51 \\
\hline 30.74 & $\mathbf{0 . 4 6}$ \\
\hline $\mathbf{0 . 4 4}$ & $\mathbf{1 . 3 8}$ \\
\hline
\end{tabular}

Interaction $(\mathrm{M} \times \mathrm{C})$

\begin{tabular}{|c|c|}
\hline 38.00 & 89.00 \\
\hline 31.52 & 80.00 \\
\hline 35.90 & 84.89 \\
\hline 37.00 & 93.08 \\
\hline 31.43 & 84.52 \\
\hline 32.81 & 88.67 \\
\hline 31.50 & 97.00 \\
\hline 26.00 & 96.00 \\
\hline 28.33 & 92.00 \\
\hline 29.69 & 98.83 \\
\hline 23.33 & 87.67 \\
\hline 28.20 & 95.00 \\
\hline 31.43 & 97.83 \\
\hline 31.33 & 88.67 \\
\hline 28.47 & 92.00 \\
\hline$*$ & $* .05$ \\
\hline $\mathbf{1 . 0 0}$ & $\mathbf{3 . 1 0}$ \\
\hline
\end{tabular}

3.10 
Table.2 Influence of the months, growing conditions and their interaction on SPAD (Chlorophyll content) and relative water content (g) of 120 days onwards Jamun softwood grafting

\begin{tabular}{|c|c|c|}
\hline Treatments & SPAD (chlorophyll content) & Relative water content \\
\hline \multicolumn{3}{|c|}{ Months (M) } \\
\hline$M_{1}$-April & 35.66 & 85.28 \\
\hline $\mathbf{M}_{2}$-May & 37.81 & 81.10 \\
\hline $\mathbf{M}_{3}$-June & 33.49 & 86.62 \\
\hline $\mathbf{M}_{4}$-July & 37.97 & 85.27 \\
\hline$M_{5}$-August & 34.92 & 79.51 \\
\hline S.Em \pm & 0.45 & 0.45 \\
\hline C.D at $5 \%$ & 1.47 & 1.48 \\
\hline \multicolumn{3}{|c|}{ Condition(C) } \\
\hline $\mathrm{C}_{1}$-Low cost polyhouse & 43.74 & 80.20 \\
\hline $\mathrm{C}_{2}$-Shade net & 35.72 & 83.00 \\
\hline $\mathrm{C}_{3}-$ Open field & 28.45 & 87.46 \\
\hline S.Em \pm & 0.26 & 0.299 \\
\hline C.D at $5 \%$ & 0.79 & 0.882 \\
\hline \multicolumn{3}{|c|}{ Interaction $(\mathbf{M} \times \mathbf{C})$} \\
\hline $\mathrm{M}_{1} \mathrm{C}_{1}$ & 44.06 & 83.21 \\
\hline $\mathrm{M}_{1} \mathrm{C}_{2}$ & 37.25 & 84.77 \\
\hline $\mathbf{M}_{1} \mathbf{C}_{3}$ & 25.67 & 87.86 \\
\hline $\mathrm{M}_{2} \mathbf{C}_{1}$ & 44.40 & 77.82 \\
\hline $\mathbf{M}_{2} \mathbf{C}_{2}$ & 36.66 & 80.37 \\
\hline $\mathbf{M}_{2} \mathbf{C}_{3}$ & 32.37 & 85.12 \\
\hline $\mathrm{M}_{3} \mathrm{C}_{1}$ & 41.39 & 82.21 \\
\hline $\mathrm{M}_{3} \mathrm{C}_{2}$ & 31.07 & 86.54 \\
\hline $\mathrm{M}_{3} \mathrm{C}_{3}$ & 28.01 & 91.10 \\
\hline $\mathbf{M}_{4} \mathbf{C}_{1}$ & 46.33 & 81.80 \\
\hline $\mathrm{M}_{4} \mathrm{C}_{2}$ & 38.50 & 85.64 \\
\hline $\mathrm{M}_{4} \mathrm{C}_{3}$ & 29.08 & 88.38 \\
\hline $\mathrm{M}_{5} \mathrm{C}_{1}$ & 42.53 & 75.99 \\
\hline $\mathrm{M}_{5} \mathrm{C}_{2}$ & 35.11 & 77.71 \\
\hline $\mathrm{M}_{5} \mathrm{C}_{3}$ & 27.11 & 84.83 \\
\hline$F$ test $(\mathrm{p} \leq 0.05)$ & $*$ & $*$ \\
\hline S.Em \pm & 0.60 & 0.67 \\
\hline C.D at $5 \%$ & 1.78 & 1.97 \\
\hline
\end{tabular}

\begin{tabular}{|c|}
\hline $\begin{array}{l}* \text { significant } \\
\mathrm{T}_{1}-\mathrm{M}_{1} \mathrm{C}_{1} \text { :April + Low cost polyhouse }\end{array}$ \\
\hline$T_{2}-M_{1} C_{2}:$ April + Shade net \\
\hline$T_{3}-M_{1} C_{3}:$ April + Open field \\
\hline $\mathrm{T}_{4}-\mathrm{M}_{2} \mathrm{C}_{1}$ :May + Low cost polyhouse \\
\hline $\mathrm{T}_{5}-\mathrm{M}_{2} \mathrm{C}_{2}: \mathrm{May}+$ Shade net \\
\hline $\mathrm{T}_{6}-\mathrm{M}_{2} \mathrm{C}_{3}:$ May + Open field \\
\hline $\mathrm{T}_{7}-\mathrm{M}_{3} \mathrm{C}_{1}:$ June + Low cost polyhouse \\
\hline $\mathrm{T}_{8^{-}}-\mathrm{M}_{3} \mathrm{C}_{2}:$ June + Shade net \\
\hline $\mathrm{T}_{9}-\mathrm{M}_{3} \mathrm{C}_{3}:$ June + Open field \\
\hline $\mathrm{T}_{10^{-}} \mathrm{M}_{4} \mathrm{C}_{1}$ :July + Low cost polyhouse \\
\hline $\mathrm{T}_{11}-\mathrm{M}_{4} \mathrm{C}_{2}:$ July + Shade net \\
\hline$T_{12}-M_{4} C_{3}: J u l y+$ Open field \\
\hline$T_{13}-M_{5} C_{1}$ :August + Low cost polyhouse \\
\hline $\mathrm{T}_{14^{-}} \mathrm{M}_{5} \mathrm{C}_{2}$ :August + Shade net \\
\hline $\mathrm{T}_{15^{-}} \mathrm{M}_{5} \mathrm{C}_{3}$ :August + Open field \\
\hline
\end{tabular}


The highest SPAD (Chlorophyll content) (37.97 $\mu$ mol per $\mathrm{m}^{2}, 43.74 \mu$ mol per $\mathrm{m}^{2}$ ) was found under the July $\left(\mathrm{M}_{4}\right)$, low cost polyhouse $\left(\mathrm{C}_{1}\right)$, respectively (Table 2). SPAD reading is higher in low cost polyhouse compared to shade net and open field conditions.

Under the polyhouse conditions, about 75 percentage of sun light were expected, graft canopy with higher or optimum temperature which result in higher metabolic rate and therefore chlorophyll condition. But chlorophyll content is poor in shade net, similarly under the open condition the quantum of light could be high that results in yellowing of leaves (Richard et al., 1990).

The Highest Relative water content $(86.62 \mathrm{~g}$, $87.46 \mathrm{~g})$ was found under the June $\left(\mathrm{M}_{3}\right)$, open field $\left(\mathrm{C}_{3}\right)$ respectively (Table 2 ).

Generally transpiration is high in open field and it's expected to have higher RWC percentage in contracts to shade net condition. Playhouse conditions very low in RWC percentage, probability the higher metabolic activity due to higher temperature relive to mite be response to lowering relative water content.

Further there could be plant strategies such has synthesis of waxes and trachoma's higher light intensity under open condition (Iuliana et al., (2012).

\section{References}

Bharad, S. And Mahorkar, V., 2009, Softwood grafting as useful method of propagation for commercial multiplication of Syzygium cumini L. Under semi-arid climatic condition of India. Act. Hort., Pp. 111-116.

Ghosh, S. N., Manna, S. and Mathew, B., 2004, Effect of season on success of grafting in custard apple under semi-arid condition of West Bengal. Hort. J., 17(1): 89-91.

Iuliana, C., Sorina, R, Giancarla, V. And Genoveva, B., 2012, Evaluation of relative water content (RWC) at four barley (Hordeum vulgare L.) genotypes in response to microwave treatment. J. Horti. Forestry. Biotechnol. 16(3): 124- 127.

Mohammad, H. M., And Mohammad, A. F. F., 2005, studies on effect of some bio fertilizer of growth of peach seedling and root disease incidence. Egypet. J. Hort., 26 (1):7-18

Mulla, B. R., Angadi, S. G., Mathad, J. C., Patil, V. S. and Mummigatti, U. V., 2011, Studies on softwood grafting in jamun (Syzygium cumini Skeels.). Karnataka J. Agric. Sci., 24 (3): 366-368.

Pampanna, Y. and Sulikeri, G. S., 1994, Effect of weather condition on the success of softwood grafting in sapota. South Indian Hort., 42:303-308.

Panse, V. G. and Ukhatne, P. V., 1967, Statistical methods for agricultural workers, ICAR, New Delhi, pp. 152-161.

Richard, J., Campbell, Kendrick, N., Mobley, Richard, P., Marini, And Douglas, G. P., 1990, Growing Conditions Alter the Relationship between SPAD-501 Values and Apple Leaf Chlorophyll. Hort. Sci., 25(3): 330-331.

Sharma, R. R. and Srivastav, M., 2004, Plant propagation \& nursery management. First Edition, International book distributing co., Charbagh, Lucknow.

Singh and Srivastava, A. K. 2000, Genetic diversity - Jamun (Sy. Cumini sheels). Indian Hort., 45 (3): 11.

\section{How to cite this article:}

Praveenakumar, R., M. Chandre Gowda and Mounashree, S. 2018. Seasonal Variability and Environmental Condition of Softwood Grafting in Jamun (Syzygium cumini Skeel). Int.J.Curr.Microbiol.App.Sci. 7(05): 3028-3032. doi: https://doi.org/10.20546/ijcmas.2018.705.353 